\title{
A Simple Method for Pineapple Seedling Propagation
}

\author{
Haiyan Shu, Keming Li, Wei Sun, Guiying Xu, Rulin Zhan*, Shenghe Chang* \\ Haikou Experimental Station, Chinese Academy of Tropical Agricultural Science, Haikou, China \\ Email: *plantfood772@hotmail.com
}

How to cite this paper: Shu, H.Y., Li, K.M., Sun, W., Xu, G.Y., Zhan, R.L. and Chang, S.H. (2019) A Simple Method for Pineapple Seedling Propagation. Agricultural Sciences, 10, 1534-1541.

https://doi.org/10.4236/as.2019.1012113

Received: November 12, 2019

Accepted: December 3, 2019

Published: December 6, 2019

Copyright $\odot 2019$ by author(s) and Scientific Research Publishing Inc. This work is licensed under the Creative Commons Attribution International License (CC BY 4.0).

http://creativecommons.org/licenses/by/4.0/

\begin{abstract}
Pineapple is nutrient and planted in many tropical and subtropical countries. Plenty of elite seedlings were always needed in short time. The common methods for propagating pineapple seedlings have low-multiplying index or take long time. A new method was introduced in this paper. Shoots were induced using stem sections. And then, the shoot bases were cut and cultured on callus-induced medium. The meristematic granules induced were cultured on shoot-induced medium. Shoots can be induced from the meristematic granules. Seedlings can be induced from these shoots in short time. This method overcomes the defects of the common ways. Enough seedlings can be gotten in short time. The operation is simple and easy to learn.
\end{abstract}

\section{Keywords}

Pineapple, Seedling, Caespitose Pathway, Callus Pathway

\section{Introduction}

Pineapple fruit is famous for its nutrition and delicious taste [1]. The trade volume of pineapple is the largest in those of tropical fruits [2]. China is one of the main countries for planting pineapple. Chinese pineapple is mainly grown in Guangdong and Hainan [3]. The major cultivar of pineapple in China is "Comte de Paris". Its cultivate area is about $80 \%$ of the total for planting pineapple [4]. The flavour of this cultivar is attractive. The shelf time of its fruit is longer than other varieties. The color of the fruit peel is vivid [2]. However, the acidity of "Comte de Paris" fruit is high, that led to low-commodity value. "Comte de Paris" fruits are always not able to be sold in harvest time in recent years. Highquality varieties of pineapple are needed for replacing "Comte de Paris". Plentiful seedlings of these varieties are wanted.

${ }^{*}$ Corresponding authors. 
Suckers, slips, hapas and crowns are always collected for pineapple seedlings [5]-[13]. After fruits were harvested, suckers, slips and hapas continued to grow for one month. And then, they were collected as seedlings. However, there were only about 10 to 20 suckers, slips and hapas for each pineapple plant. When plentiful seedlings were wanted, seedlings from these were not enough. Furthermore, they cannot be supplied at all time. Comparatively, seedlings from tissue culture can be operated in labs and can be gotten at all time. Propagating seedlings through tissue culture can overcome this defect. Tissue culture included caespitose pathway and callus pathway. Commonly, caespitose shoots or callus were used for multiplying pineapple seedlings from tissue culture. The reproducing index of caespitose pathway for pineapple is low. Some researchers reported that only 1 or 2 seedlings can be induced from one explant. The highest index reported for reproducing pineapple seedlings through caespitose method was 12 [14]-[20]. This was insufficient when large number of seedlings were needed. Substantive seedlings can be gotten from an explant through callus pathway. However, this method always takes several months and. the technology required is strict. It is hard to spread this method in practice.

The aim of this paper was to study a new method for multiplying pineapple seedlings. This method can overcome the shortcomings of caespitose pathway and callus pathway described above. Large number of seedlings can be gotten in short time. Workers can operate after being simply trained.

\section{Materials and Methods}

The pineapple variety used in this paper was Tainong 16, whose fruits have high content of fructose and low acidity. This variety was welcomed in markets.

Pineapple plants were grown in Nada, Danzhou, China. On June 15, 2019, when fruits were harvested one month later, suckers, slips or hapas were collected from mother plant. Leaves were removed and the stem was washed sufficiently with $1 \%$ of detergent. And then, the stem was washed with tap water. All of the attachments on the surface of the stem were removed. The stems were sprayed with $75 \%$ of ethanol. In superclean bench, the stems were immersed in $75 \%$ of ethanol for one minute. And then, they were taken and washed with sterilized water five times. One minute for each time. After that, the stems were put in a petri dish whose diameter was $9 \mathrm{~cm}$. The top and the bottom of the stems were cut using scalpel. The middle part whose length was about $0.5 \mathrm{~cm}$ was put on culturing medium M1. The formulation of M1 was MS + $1.5 \mathrm{mg} / \mathrm{L} 6-\mathrm{BA}+$ $0.1 \mathrm{mg} / \mathrm{L}$ NAA [21] [22]. The explants were cultured in dark for 15 days. The temperature was $26^{\circ} \mathrm{C}$ and the photoperiod was 12-hour light/12-hour dark. The luminous intensity was 1500 lux.

After shoots appeared from stem section, the shoot with base was cut. The top of the shoots were removed and the shoot base was cultured on callus-induced medium M2. The formulation of M2 was MS + $2.0 \mathrm{mg} / \mathrm{L}$ 2,4-D + $1.5 \mathrm{mg} / \mathrm{L}$ 6-BA $+0.1 \mathrm{mg} / \mathrm{L} \mathrm{NAA}+30 \mathrm{~g} / \mathrm{L}$ Sucrose $+7 \mathrm{~g} / \mathrm{L}$ Agar, $\mathrm{pH}=5.3$ [21] [22]. The injured 
surface was pasted on the medium. The culturing bottles were put in dark and the temperature was $26^{\circ} \mathrm{C}$. The explants were subcultured every two weeks. After one month, some meristematic granules appeared. These granules were cut and put on shoot-induced medium M1 and cultured for two weeks in dark at $26^{\circ} \mathrm{C}$. And then, the bottles were transferred to light-culture incubator. The photoperiod was 12-hour light/12-hour dark. The light intensity was 1500 lux. The temperature was $26^{\circ} \mathrm{C}$. After one month, plenty of shoots can be gotten from the granules. When shoot length reached to $3 \mathrm{~cm}$, the shoots were divided and subcultured onto medium M3. The formulation of M3 was MS + 5\% coconut milk + $30 \mathrm{~g} / \mathrm{L}$ sucrose, $\mathrm{pH}=5.8$. The photoperiod was 12 -hour light/12-hour dark. The light intensity was 1500 lux. The temperature was $26^{\circ} \mathrm{C}$. After two weeks, the shoots were transferred onto medium M4. The formulation of M4 was 1/2 MS + $0.5 \mathrm{mg} / \mathrm{L} \mathrm{IBA}+3 \%$ banana powder $+30 \mathrm{~g} / \mathrm{L}$ sucrose, $\mathrm{pH}=5.8$. The photoperiod was 12 -hour light/12-hour dark. The light intensity was 1500 lux. The temperature was $26^{\circ} \mathrm{C}$. After one month, the lid of the culturing bottle was removed and the bottle was put in shady shed for 3 days. And then, the seedlings were taken out and the residual medium on roots was removed by being washed with tap water. The seedlings were grown in pot containing gardening soil. After being grown in shady shed for 3 days, the seedlings were transferred to natural light to grow.

\section{Results}

1) Shoots gotten from stem section through caespitose pathway was few

The stem sections were cultured on caespitose-induced medium for three months. However, many sections had not grown shoots. Although there were shoots appeared on some sections, the shoots were very few (Figure 1). This might be due to that there were few grown points on the stem sections. If the thicker sections with more grown points were cultured, there might be more shoots gotten.

2) Few callus were gotten after stem section was cultured on callus-induced medium
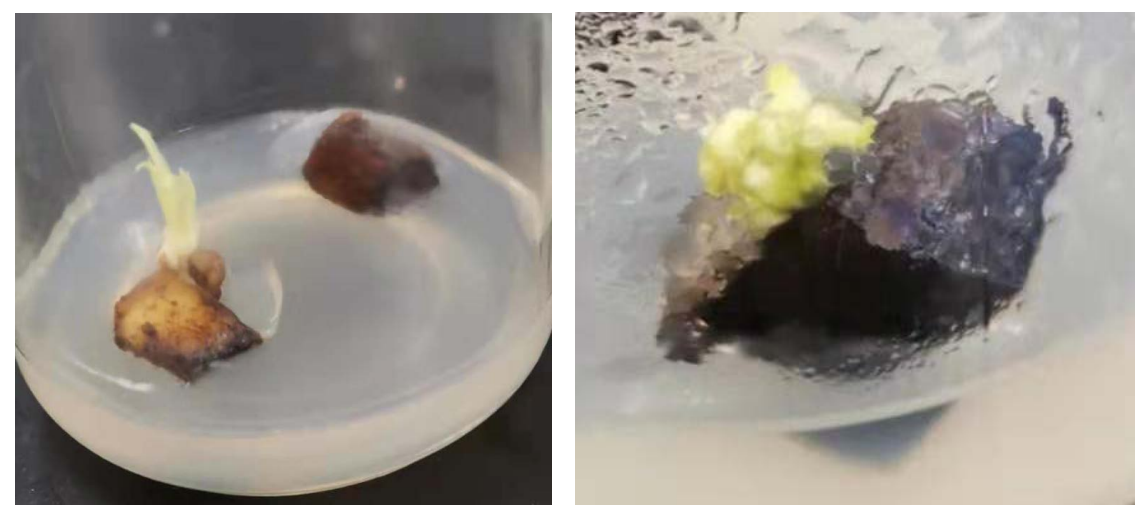

Figure 1. Shoots induced from stem sections of pineapple. 
After stem sections were cultured on callus-induced medium for three months, there were very few callus gotten (Figure 2(a) and Figure 2(b)). Theoretically, the explants whose states are nearer to zygote are easier to be induced to embryogenesis. Cells in stem sections have been differentiated highly from the embryo state. It was difficult to induce callus from stem sections.

3) Shoots can be induced from granules and the propagating index was high

After the shoots appeared on stem sections, they were cut with the shoot bases. The shoot was removed and the base was cultured on callus-induced medium. After one month, meristematic granules appeared around the shoot base (Figure 3). These granules were transferred onto shoot-induced medium M1 and cultured for one month, plenty of little shoots can be found from the granules (Figure 4). After the shoots were cultured in light, they can grow into seedlings quickly (Figure 4 and Figure 5). After the seedlings were divided and grown enough, they can be transferred to pot containing gardening soil and continued to grow (Figure 6).

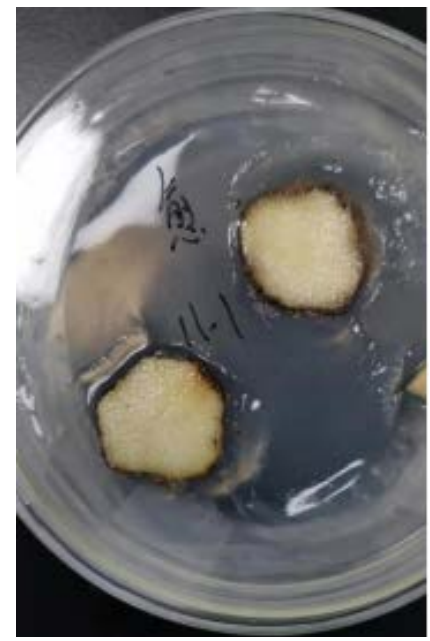

(a)

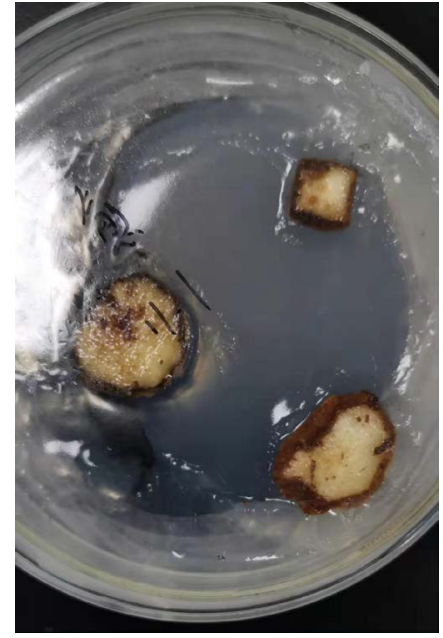

(b)

Figure 2. Pineapple-stem sections were cultured on callus-induced medium. (a) Showed stem sections without callus; (b) Showed that there were a few callus induced.
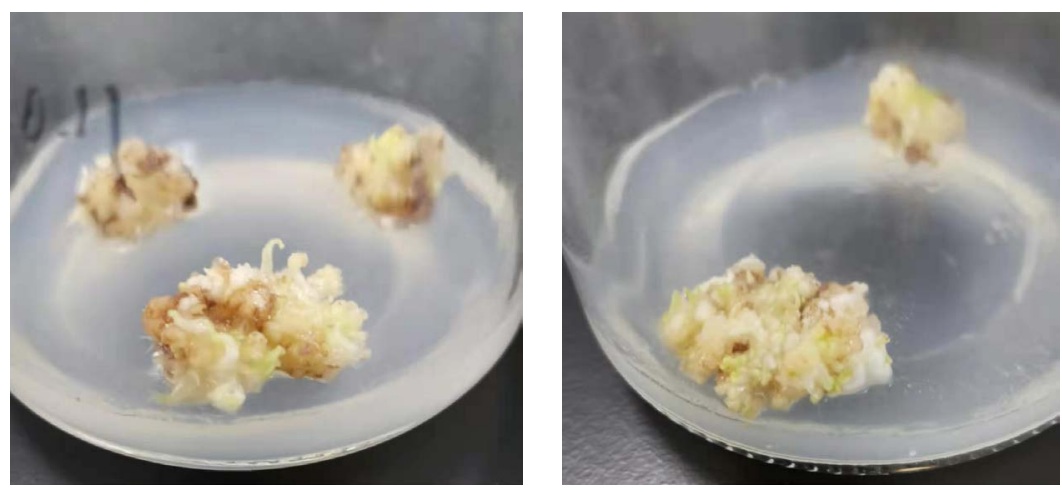

Figure 3. Meristematic granules were induced around shoot bases on callus-induced medium. 

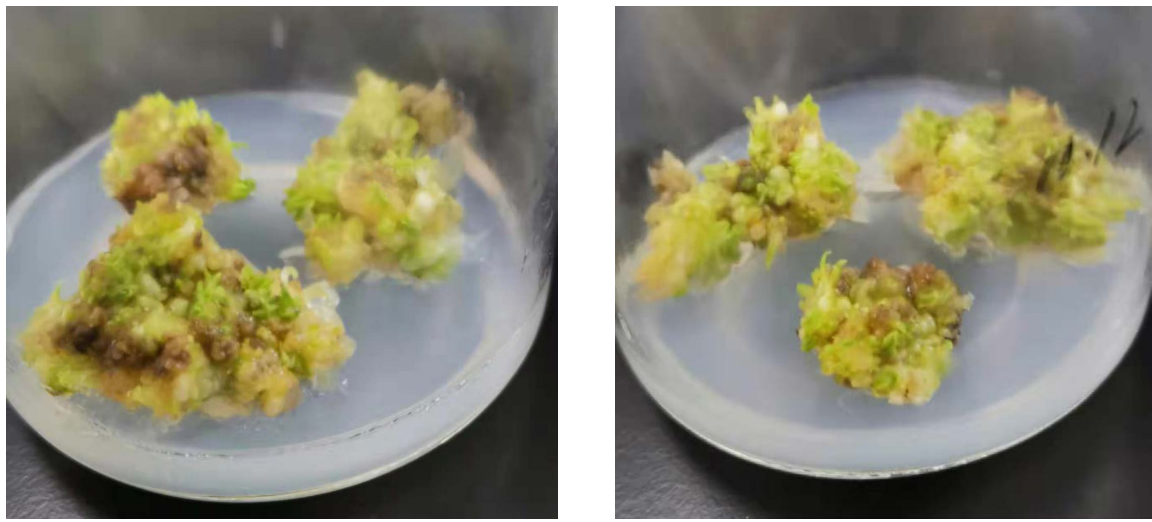

Figure 4. Plenty of shoots were gotten after meristematic granules were induced on shoot-induced medium.
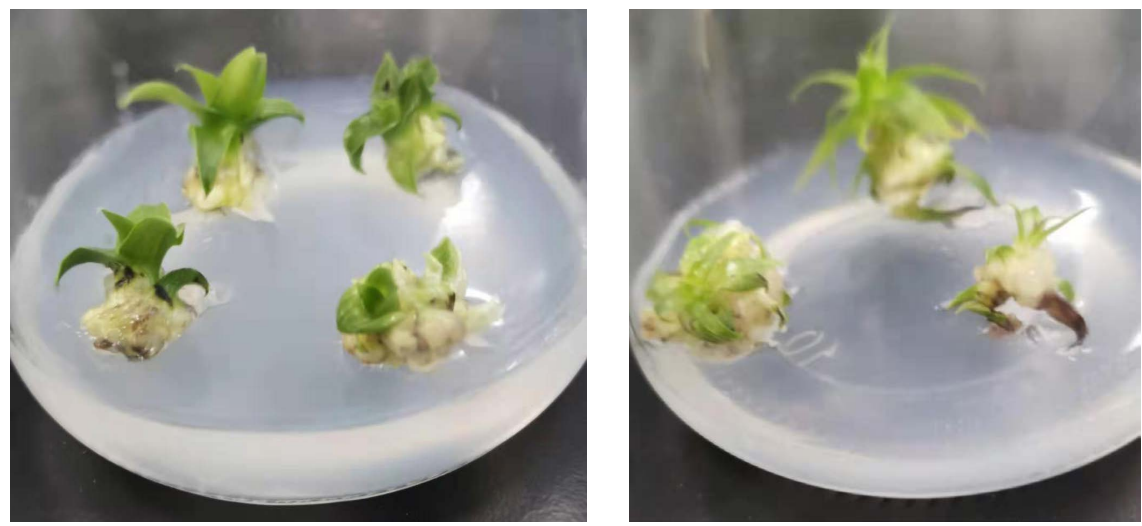

Figure 5. Shoots were divided and subcultured.

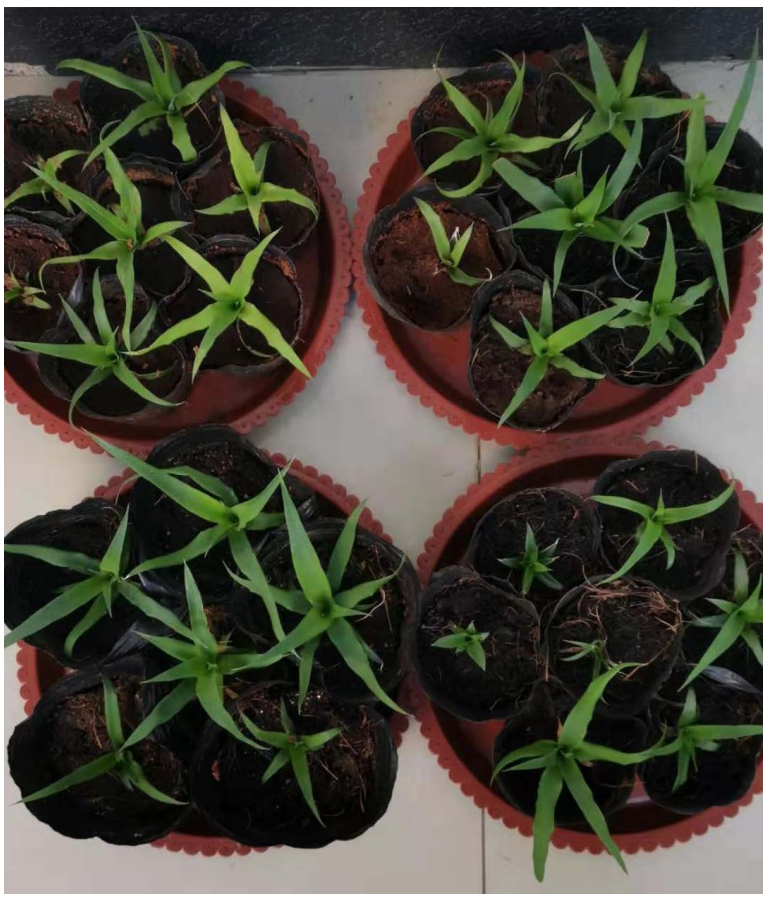

Figure 6. Seedlings were cultured in pot containing gardening soil. 


\section{Discussion}

Seedlings gotten from explants through caespitose pathway is organogenesis fundamentally [23]. Shoots gotten on stem sections of pineapple through caespitose pathway are few. The reason might be due to that there were few shoot points in the stem sections used for explants. If thicker sections with more shoot points were used as explants, more shoots might be gotten.

There were few callus gotten when stem sections were cultured on callus-induced medium. This demonstrated that it was hard to induce callus from somatic cells of pineapple. Theoretically, callus induced from pineapple explants included embryogenic callus and nonembryogenic callus [24]. Seedlings can only be induced from embryogenic callus. This needed much hard work [25] [26]. It seemed that callus induced from shoot base in this paper were meristematic granules. After these granules were cultured on shoot-induced medium, shoots can be induced, indicating that these granules had embryogenic characteristics. If they were differentiated fully, they can be induced into whole seedlings.

If only caespitose pathway was used for propagating seedlings, explants with many shoot points should be used. The multiplying index was low. The callus-pathway is a hard work to operate. It took long time. The method used in this paper combined caespitose pathway and callus pathway. Many meristematic granules can be induced from shoot base and plenty of seedlings can be gotten in short time. The reproducing index was significantly higher than that of caespitose pathway. The shortcomings of callus pathway that the operation is hard and it took long time were overcome in this method. Enough seedlings of pineapple can be gotten in short time.

\section{Conclusion}

A new method was invented to propagate pineapple seedlings in this paper. Shoots were induced from stem sections firstly. Shoot bases were cultured on callus-induced medium. The meristematic granules induced were cultured on shoot-induced medium. Shoots can be induced on meristematic granules. Seedlings can be gotten in short time. This method overcomes the defects of the common ways. Enough seedlings can be gotten in short time.

\section{Acknowledgements}

This paper was supported by The Funds of Ministry of Agriculture and Rural Affairs of the People's Republic of China for Measuring and Controlling the Epidemic Situation of Disease, Pests, and Rats in Crops.

\section{Conflicts of Interest}

The authors declare no conflicts of interest regarding the publication of this paper. 


\section{References}

[1] Akbar, M.A., Karmakar, B.K. and Roy, S.K. (2003) Callus Induction and HighFrequency Plant Regeneration of Pineapple (Ananas comosus (L.) Merr.). Plant Tissue Culture, 13, 109-116.

[2] He, J.H., Chen, H.R., Huang, H.J., Wang, J.H. and Huang, H.N. (2015) The New Varieties and High-Quality- and High-Production-Cultivation Technology of Pineapple (Ananas comosus L.). China Agricultural Science and Technology Press, Beijing.

[3] Shu, H., Sun, W., Li, K., Xu, G., Zhan, R. and Chang, S. (2019) The Cause for Water-Heart Fruit of Pineapple and Protective Measurements. American Journal of Plant Sciences, 10, 885-892. https://doi.org/10.4236/ajps.2019.106063

[4] Shu, H., Sun, W., Li, K., Xu, G., Zhan, R. and Chang, S. (2019) The Situation and Challenges of Pineapple Industry in China. Agricultural Sciences, 10, 683-688. https://doi.org/10.4236/as.2019.105053

[5] Benega, R., Isidron, M.J., Hidalgo, M. and Borroto, C.G. (1995) In Vitro Regeneration and Callus Formation in Pineapple (Ananas comosus (L.) Merr.) Hybrid Seed. Acta Horticulturae, 425, 215-220. https://doi.org/10.17660/ActaHortic.1997.425.26

[6] Cote, F.R., Domergue, R., Follit, M., Bouffin, J. and Marie, F. (1991) In Vitro Micropropagation of Pineapple. Fruits Paris, Numero Special Ananas, 46, 359-366.

[7] Daquinta, M., Castillo, R., Lorenzo, C., Lunas, I., Escalona, M., et al. (1994) Formation de callos en pina (Ananas comosus (L.) Merr.). Revista Brasileira de Fruticultura, 16, 83-91.

[8] De Wald, M.G. (1988) Tissue Culture and Electrophoretic Studies of Pineapple (Aananas comosus) and Related Species. International B, Science and Engineering, 48,8 .

[9] Khatun, M.M., Khanam, D., Hoque, M.A. and Quasem, A. (1997) Clonal Propagation of Pineapple through Tissue Culture. Plant Tissue Culture, 7, 143-148.

[10] Lakshmi, S.G., Singh, R. and Layer, C.P.A. (1974) Plantlets through Shoot Tip Culture in Pineapple. Current Science, 43, 724.

[11] Mathews, V.H. and Rangan, T.S. (1979) Multiple Plantlets in Lateral Buds and Leaf Explants in in Vitro Cultures of Pineapple. Scientia Horticulturae, 11, 319-326. https://doi.org/10.1016/0304-4238(79)90016-5

[12] Rahman, K.W., Amin, M.N. and Azad, M.A.K. (2001) In Vitro Rapid Propagation of Pineapple, Ananas comosus (L.) Merr. Plant Tissue Culture, 11, 47-53.

[13] Roostika, I., Khumaida, N., Mariska, I. and Wattimena, G.A. (2012) The Effect of Picloram and Light on Somatic Embryogenesis Regeneration of Pineapple. Indonesian Journal of Agricultural Science, 13, 43-53.

[14] Aydieh, A.A., Ibrahim, M.K.H. and Ibrahim, A. (2000) In Vitro Propagation and Fruiting of Pineapple. Egyptian Journal of Horticulture, 27, 289-304.

[15] Be, L.V. and Debergh, P.C. (2006) Potential Low Cost Micropropagation of Pineapple (Ananas comosus). South African Journal of Botany, 72, 191-194. https://doi.org/10.1016/j.sajb.2005.07.002

[16] Bhatia, P. and Ashwath, N. (2002) Development of Rapid Method for Micropropagation of a New Pineapple (Ananas comosus (L.) Merr. Clone Yeppoon Gold. Acta Horticulturae, 575, 125-131. https://doi.org/10.17660/ActaHortic.2002.575.11

[17] Firoozabady, E. and Gutterson, N. (2003) Cost Effective in Vitro Prapagation Methods for Pineapple. Plant Cell Reports, 21, 844-850. 
[18] Sripaoraya, S., Marchant, R., Power, J.B. and Davey, M.R. (2003) Plant Regeneration by Somatic Embryogenesis in Commercial Pineapple (Ananas comosus L.). In Vitro Cellular \& Developmental Biology-Plant, 39, 450-454. https://doi.org/10.1079/IVP2003445

[19] Zepeda, C. and Sagawa, Y. (1981) In Vitro Propagation of Pineapple. Horticultural Science, 16, 495.

[20] Al-Saif, A.M., Hossain, A.B.M.S. and Taha, R.M. (2011) Effects of Benzylaminopurine and Naphthalene Acetic Acid on Proliferation and Shoot Growth of Pineapple (Ananas comosus L. Merr) in Vitro. African Journal of Biotechnology, 10, 5291-5295. https://doi.org/10.5897/AJB11.370

[21] Jiang, L. (2006) Study on Establishment of Genetic Transformation System of Pineapple (Ananas comosus (L) Merr) Tainong-16 and Gene Transfer of Resveratrol Synthase into Pineapple. Chinese Agricultural University, Beijing.

[22] Xu, Y. (2006) Studies on Rapid Propagation and Polyploid Breeding of Ananas comosus (L.) Merrill. Southwest University, Chongqing, China.

[23] Firoozabady, E. and Moy, Y. (2004) Regeneration of Pineapple Plants via Somatic Embryogenesis and Organogenesis. In Vitro Cellular \& Developmental BiologyPlant, 40, 67-74. https://doi.org/10.1079/IVP2003494

[24] Iwase, A., Ohme-Takagi, M. and Sugimoto, K. (2011) WIND1, A Key Molecular Switch for Plant Cell Dedifferentiation. Plant Signaling \& Behavior, 6, 1943-1945. https://doi.org/10.4161/psb.6.12.18266

[25] Strosse, H., Domergue, R., Panis, B., Escalant, J. and Cote, F. (2001) Banana and Plantain Embryogenic Cell Suspensions. INIBAP Technical Guidelines, Montpellier Cedex.

[26] Cote, F.X., Domergue, R., Monmarson, S., Schwendiman, J., Teisson, C., et al. (1996) Embryogenic Cell Suspensions from the Male Flower of Musa AAA cv. Grand Nain. Physiologia Plantarum, 97, 285-290. https://doi.org/10.1034/j.1399-3054.1996.970211.x 